\title{
Migration Policy in the Context of Sustainable Development
}

\author{
NATALIIA TKACHOVA ${ }^{1}$, TAISIIA KRUSHELNYTSKA ${ }^{2}$, OKSANA MARCHENKO $^{3}$, \\ NATALIYA KUZNETSOVA ${ }^{4}$
}

\author{
${ }^{1}$ Department of Information and Communicative Technologies of Business Education, National \\ Aviation University, Kyiv, UKRAINE \\ ${ }^{2}$ Departament of Economics and Regional Economic Policy, Dnipropetrovsk Regional Institute for \\ Public Administration, National Academy for Public Administration under the President of Ukraine, \\ UKRAINE \\ ${ }^{3}$ Department of Economics and Hotel and Restaurant Business Bogdan Khmelnitsky Melitopol State \\ Pedagogical University, UKRAINE \\ ${ }^{4}$ Department of Economics, Entrepreneurship and Marketing, Cherkasy State Business College, \\ UKRAINE
}

\begin{abstract}
The issues of sustainable development are related to the need in order to reduce poverty, inequality, insecurity, inclusion of immigrants in the system of education and health care, which contradicts the effective long-term solution of the global goals of EU migration policy. The aim of the research is to study the effectiveness of migration policy in the context of sustainable development on the example of EU countries in order to formulate proposals for overcoming the problems of inequality and poverty as priority goals. The results of the research complement the theory of the new economics of labour migration, considering this concept as a way to maximize income and reduce the risk of revenue through education, higher wages and a way to get better health and education services, access to developed infrastructure. However, the heterogeneity of the effects of migration is also reflected in the inability to obtain health services and access to the education system due to the high cost. All this exacerbates the problems of inequality and poverty due to the imbalance of both income and the cost of social services in different EU countries. It has been determined that the policy of integration of immigrants does not ensure the achievement of the goal of inclusive and equitable socialeconomic welfare. Inequality, in particular, gender one remains the main problem of sustainable development through illegal employment and different levels of remuneration. It has been proved that training should be considered in the context of sustainable development as providing access to the education system and programs. Despite the growing participation in educational programs and training of immigrants, the problems of inequality and poverty remain a priority for ensuring sustainable development.
\end{abstract}

Key-Words: - Migration Policy, Sustainable Development and Migration, Migration Flows, Migration Management Strategies

Received: October 2, 2020. Revised: February 24, 2021. Accepted: March 19, 2021. Published: April 2, 2021.

\section{Introduction}

Over the last twenty years, migration policy has been viewed in the context of sustainable development for a number of reasons. Political approaches to public management of migration flows have begun to align with sustainable development strategies in order to ensure national coordination and international cooperation. The integration of migrants into the labour market and the control of migration flows have been major obstacles to the unification of political approaches. Along with this, there is the problem of sustainable development related to overcoming poverty, inequality [1], lack of security, which contradicts the effective long-term solution of the global goals of EU migration policy [2]. "The intertwined nature of environmental, ethnic, and poverty problems not only bears negatively upon the "alleviation of poverty conducing to the accruement of wealth" of the poverty-stricken population, but also hinders the rehabilitation of the environment" [3].

Thus, there is a conflict between the interests and goals of migration policy and sustainable development policy. On the one hand, highly qualified migrants contribute to development in high-income countries; they act as channels for technology transfer through knowledge, investment [4]. On the other hand, low-skilled migrants cause a 
significant burden on the state budgets of EU countries and the growing need for social protection $[5 ; 6]$. For instance, $55 \%$ of migrants worldwide are entitled to social protection. However, some groups of migrants do not have social protection and rights due to illegal employment and labour market features. In particular, this applies to female immigrants in the sphere of care and medicine [7]. Despite the recent trend towards sustainable development of migration, there are also problems with the growth of the illegal number of migrants.

Policies should be aimed at effectively controlling large migration flows in order to ensure the stability of the education system, quality of life, reducing the level of pressure in host countries [8], reducing the gap between high and low skilled migrants [9]. At the same time, reducing migration is ineffective and costly, that requires an actual management policy which based on the expansion of migration programs as a tool for sustainable development.

The purpose of the academic paper is to study the effectiveness of migration policy in the context of sustainable development on the example of EU countries in order to formulate proposals towards overcoming inequality and poverty as priority goals.

\section{Literature Review}

Migration and sustainable development are interlinked with such phenomena, as: international labour mobility, inequality and security [2]. "Despite the often considerable benefits of migration and remittances for individuals and communities involved, migrants alone can generally not remove more structural development constraints and migration may actually contribute to development stagnation and reinforce the political status quo" [10]. First and foremost, migration is a reason to stimulate the development of human capital retention policies in order to structurally change the labour market, increase wages in national markets, develop social services and infrastructure; whereas the classical approach to understanding migration interpreted the concept as obtaining short-term benefits from remittances, diversifying the risk of household income. The paradigm of sustainable development served as a basis for the development of a policy of "wellordered and responsible migration", which helps reduce inequality, poverty, increase security. On the other hand, migration should be considered from the point of view of the prerequisites for structural transformations of the economy in the context of the development of the education and health care system, infrastructure and technologies as prerequisites for balanced migration.
Migration is a source of income for developing countries through remittances, foreign direct investment, technology transfer, tourism, investment in human capital; it stimulates local economic development $[6 ; 11]$. The flipside of this process is the increase in gender inequality, in particular, through the feminization of migration and the concentration of female labour in low-skilled, lowpaid sectors. As a result, migrants' cash flows are directed to current expenditures and may not stimulate economic development but increase poverty in a developing country. "The income stream lasts only as long as migration lasts, and, thus, is vulnerable to changes in receiving country immigration policies as well as the continued attachment of long-term immigrants to the home country" [11]. Such trends are most evident in the least developed and poor countries, where the level of manifestation of the multiplier effect of investments from migrant remittances is low. Highly skilled migrants with professional skills are the exception (Gelb \& Krishnan, 2018); they provide a significant contribution to the economy through knowledge, technology, investment in their own development and taxes. "The debate on migration and development has swung back and forth like a pendulum, from developmentalist optimism in the 1950s and 1960s, to neo-Marxist pessimism over the 1970s and 1980s, towards more optimistic views in the 1990s and 2000s" [12]. The change in social theory has led to a transnational turn in the investigation of migration. Pluralistic, structuralist and hybrid approaches sought to ensure a reconciliation of pessimist and optimist approaches in this area of the research. Since the 2000 s, the volume of research on development and migration has grown significantly. In general, despite the complexity of assessing the impact of migration on sustainable development, this phenomenon provides positive economic benefits for the labour market, as well as social and fiscal effects [9]. For industrialized countries with an aging population, migrants are a source of labour, for rural areas - they can stimulate regional development [13]. Along with this, empirical studies prove the heterogeneity of migration effects for different regions and countries.

Migration and development have been the topic of constant heated debate in the social scientific researches for at least half a century in the 1950s and 1990s. Two opposing approaches can be broadly distinguished in this discussion, namely: the theory of "balanced growth" versus the critical theory of "asymmetric development". Alternatively, they can be called "migration optimists" and 
"migration pessimists". Migration optimists tend to emerge from neoclassical migration economy and/or modernization theories. Despite significant differences between neoclassical and developmental views - especially different roles, they attribute to the state, they both believe that migration has generally had a positive effect on the development process at departure points. Most migratory pessimists use a social theory that includes neoMarxism, dependence, and the theory of world systems [10]. In general, structuralist approaches to migration and development tend to interpret migration as a negative phenomenon that contributes to the further underdevelopment of the economies of migrants' birthplaces and derogation of their social-cultural cohesion [12].

The link between sustainable development and migration is defined as a two-way close link $[1 ; 10$; 14]; it is characterized by cointegration. Collective commitments towards achieving the goals of sustainable development in the context of the development of migration policy, social protection and the labour market are a more frequent subject of the scientific research [7]. Some relevant studies can be found in [15] and [16].

Thus, the analysis of the scientific literature provides evidence of the formation of a new paradigm of migration, where it is considered as a tool for obtaining a wide range of assets in the narrow sense in terms of households and individuals. From a broader macroeconomic perspective, migration is considered as ensuring sustainable development through economic growth due to human capital flows.

\section{Methodology}

The theoretical basis of the present research has been built on De Haas's pluralistic approach to migration, which suggests the importance of structure for addressing the heterogeneity of migration impacts. In addition, De Haas systematizes the theory of "The new economics of labour migration", according to which migration is modelled as the behaviour of families or households to distribute the risks arising from income [12]. Migration is understood as a reaction to income risk, forasmuch as remittances insure households against poverty. This theory explains migration in the absence of income disparities in different countries. "A livelihood encompasses not only the households' income generating activities, but also the social institutions, intrahousehold relations, and mechanisms of access to resources through the life cycle. For their livelihoods, people and households draw on five categories of assets (or capitals): natural, social, human, physical, and financial" [10].

The indicators of migration integration of $\mathrm{EU}$ Eurostat countries for 2010-2019 have been used in the research in order to conduct a statistical correlation analysis of policy effectiveness in the context of sustainable development. The main indicators for analysis are identified as follows: 1) Recent immigrants aged from 15 to 64 in EU-27 2010-2019, \% of total population; 2) Participation rate in education and training (last 4 weeks) of immigrants from foreign country, \% from 18 to 64 ; 3) Population (employed immigrants), thousand 1564 ; 4) At-risk-of-poverty rate of immigrants in EU27 (population aged 18 and over), \%; 5) Median equivalised net income of immigrants in EU-27 (population aged 18 and over), Purchasing power standard (PPS); 6) Self-reported unmet needs of immigrants for medical examination due to expensiveness (16 years and over), \%; 7) Immigrants suffering from long-term unemployment (12 months or more) as a percentage of the total unemployment; 8) Gross domestic product at market prices (Current prices, euro per capita); 9) Labour productivity and unit labour costs in EU-27; 10) Compensation per employee, euro; 11) Compensation of employees per hour worked, euro; 12) Real labour productivity per person (Index, 2015=100); 13) Unemployment in EU-27, \% of total population aged $15-74 ; 14)$ Unemployment in EU$27, \%$ of active population aged 15-74.

Pairwise correlation was used to analyse the relationship between the indicators, and the results of the obtained calculations were summarized as a matrix. The analysis of the structure of the presented correlation matrix was performed taking into account the comparison of correlation coefficients based on the Chaddock scale.

The basic components of assessing the effectiveness of migration policy in the context of sustainable development are as follows: 1) education; 2) medicine; 3) income and wages; 4) poverty and inequality; 5) contribution to economic growth, productivity and reduction of unemployment. These components most fully reflect the heterogeneity of the new economics of labour migration.

\section{Results}

EU migration policy aims to integrate immigrants into the society through access to education, health care and social protection. Inclusion of migrants is becoming a priority of sustainable development policy at the international level, however, the 
governments of the countries over the past ten years have not ensured significant changes to improve the quality of life of certain groups. The growth of migration flows requires the inclusion of immigrants. Within EU, the share of immigrants increased significantly in 2010-2019, both among member states and from other countries. Along with this, the largest share of migrants is observed from foreign countries (Figure 1) [17]. The largest share of immigrants from non-EU countries is observed in Malta (6,8\%), Cyprus (6,3\%), Sweden $(6,0 \%)$, Germany (3,0\%), Switzerland $(3,1 \%)$, Ireland $(4,1 \%)$, Austria $(2,5 \%)$, and Denmark $(1,9 \%)$.

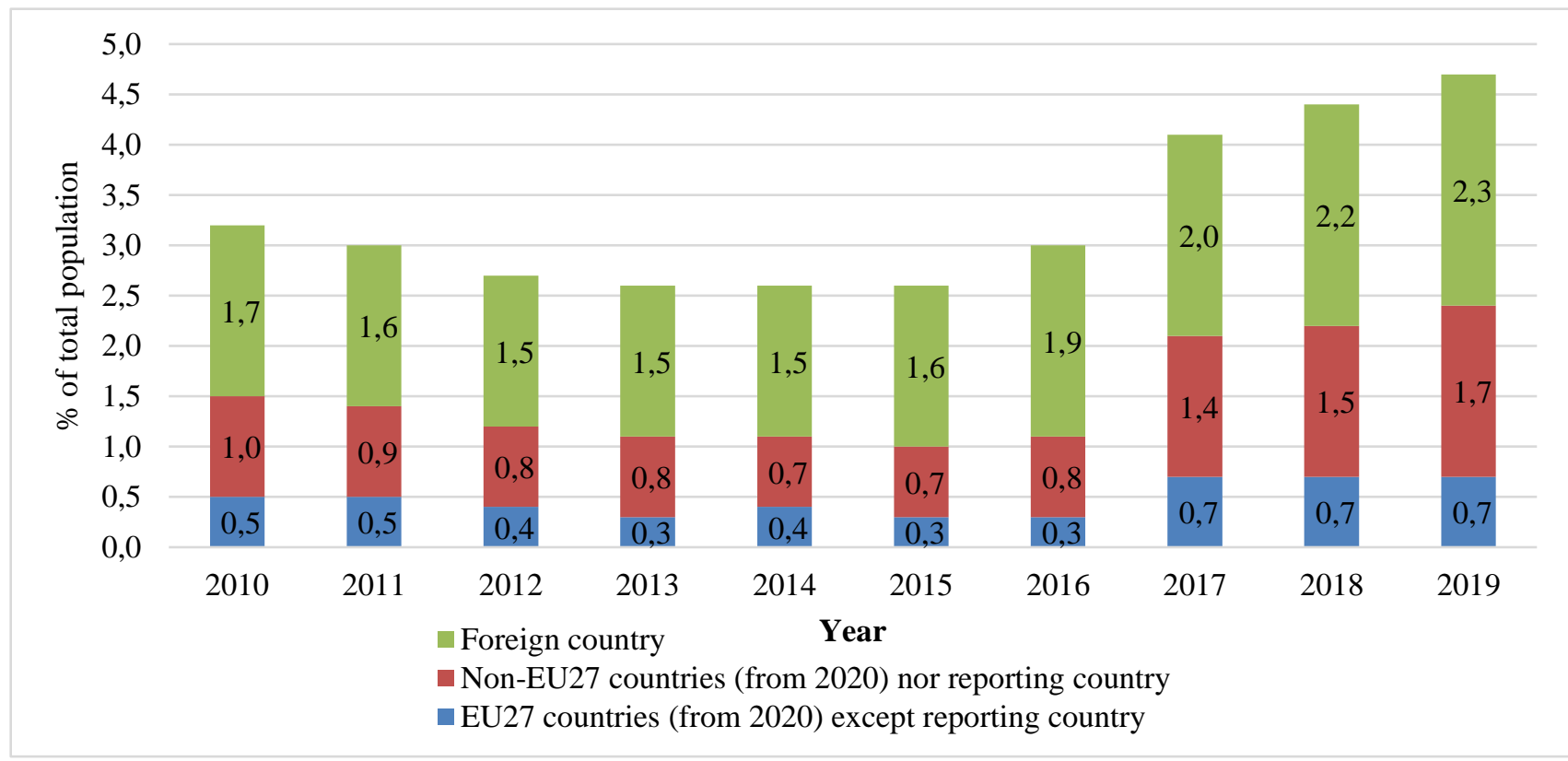

Fig. 1. Recent immigrants aged from 15 to 64 in EU-27 2010-2019, \% of total population

Indicators of immigrants' integration in the EU (see table 1) provide evidence of an increase in the level of skills through immigrants participation in educational programs and trainings (the share is $14,1 \%)$, an increase in the number of employed immigrants (an increase of 11185 people in 20102019). Herewith, the level of risk of immigrant poverty in the EU remained unchanged - at the level of $15 \%$, which means both the lack of effectiveness of social protection policy and the systemic problem of low skills of immigrants and the inability to find employment. In terms of purchasing power, the average income of EU immigrants exceeded the average income of immigrants from other countries by 4068 euros in 2019 (2 778 in 2010). This means the systematic nature of the problem of inequality in labour remuneration, in particular, in less developed countries, despite the growth in wages of immigrants. Herewith, the level of remuneration of EU citizens significantly exceeds the income of immigrants - the amount of compensation for EU workers amounted to 37081 euros in 2019, having increased by 4673 euros over ten years. This means even greater inequality in wages. It should be noted that EU unemployment rate decreased significantly in 2010-2019, namely: by $1,9 \%$ among the total population and by $3,1 \%$ among the economically active population. GDP per capita also increased by 5520 euros. On the other hand, medical services, despite the rise in wages for immigrants, remain inaccessible due to the high cost, especially for immigrants from non-EU countries.

Table 1. Migrant integration indicators and economic development indicators in EU-27, 2010-2019

\begin{tabular}{|c|c|c|c|}
\hline Indicator & 2010 & 2019 & Growth, +/- \\
\hline $\begin{array}{l}\text { Participation rate in education and training (last } 4 \text { weeks) of immigrants } \\
\text { from foreign country, } \% \text { from } 18 \text { to } 64\end{array}$ & 11,7 & 14,1 & 2,4 \\
\hline Population (employed immigrants), thousand 15-64 & 183703,9 & 194888,9 & 11185,0 \\
\hline $\begin{array}{l}\text { At-risk-of-poverty rate of immigrants in EU-27 (population aged } 18 \text { and } \\
\text { over), } \%\end{array}$ & 14,5 & 14,8 & 0,3 \\
\hline Median equivalised net income of immigrants in EU-27 (population aged & 13894 & 16514 & 2620,0 \\
\hline
\end{tabular}


18 and over), Purchasing power standard (PPS)

\begin{tabular}{|c|c|c|c|}
\hline EU-27 countries (from 2020) except reporting country & 15283 & 18548 & 3265,0 \\
\hline Non-EU-27 countries (from 2020) nor reporting country & 12505 & 14480 & 1975,0 \\
\hline $\begin{array}{l}\text { Self-reported unmet needs of immigrants for medical examination due to } \\
\text { expensiveness ( } 16 \text { years and over), } \%\end{array}$ & 2,00 & 0,95 & $-1,1$ \\
\hline EU-27 countries (from 2020) except reporting country & 1,4 & 0,8 & $-0,6$ \\
\hline Non-EU-27 countries (from 2020) nor reporting country & 2,6 & 1,1 & $-1,5$ \\
\hline Foreign country & 2,1 & 1,0 & $-1,1$ \\
\hline $\begin{array}{l}\text { Immigrants Long-term unemployment ( } 12 \text { months or more) as a } \\
\text { percentage of the total unemployment }\end{array}$ & 39,3 & 37,0 & $-2,3$ \\
\hline Gross domestic product at market prices (Current prices, euro per capita) & 25640 & 31160 & 5520,0 \\
\hline \multicolumn{4}{|l|}{ Labour productivity and unit labour costs in EU-27 } \\
\hline Compensation per employee, euro & 32408,1 & 37081,6 & 4673,5 \\
\hline Compensation of employees per hour worked, euro & 20,5 & 23,8 & 3,3 \\
\hline Real labour productivity per person (Index, 2015=100) & 98,2 & 103,2 & 5,0 \\
\hline Unemployment in EU-27, \% of total population aged 15-74 & 6,2 & 4,3 & $-1,9$ \\
\hline Unemployment in EU-27, \% of active population aged 15-74 & 9,8 & 6,7 & $-3,1$ \\
\hline
\end{tabular}

Indicators of the integration of immigrants over ten years do not indicate the ineffectiveness of EU migration policy: in general, the quality of life of foreigners has not improved significantly, and wage growth is likely to be due to structural changes and external variables. Despite the proclamation of the need to reduce inequality within the framework of the concept of sustainable development, integration policy addresses little to solve the problems of gender inequality, poverty and the quality of foreigners' life. At the same time, there is a stable growth of GDP and a decrease in unemployment within EU, while the share of long-term unemployment among immigrants is 37\% in 2019.

Gender inequality is among the problems of migration policy; it is manifested in particular in the higher risk of poverty of female immigrants compared to male immigrants (18 years and older). For instance, in 2010 the at-risk-of-poverty rate among female immigrants was $15,3 \%$ within the EU-27, in 2019 - 15,6\%, especially in Eastern Europe (Bulgaria - 23,5\% , Estonia - 22,4\%, Latvia - 25,6\%, Lithuania - 22,5\%, Romania - 23,7\%, Serbia - 23,0\%). In developed EU countries, migration policy provides a solution to the problem of poverty of female immigrants, as evidenced by a reduction in the risk of poverty, namely: Belgium $11,7 \%$ in 2010 and $10,9 \%$ in 2019 , Greece - 18\% and $-15,9 \%$ respectively, Spain $-17,1 \%$ and $16,2 \%$ respectively, Austria - $11,8 \%$ and $11,0 \%$ respectively, France $-11,4 \%$ and $10,9 \%$. Exceptions are as follows: Germany $(15,8 \%$ and $16,3 \%)$, Italy $(18,1 \%$ and $18,9 \%)$, the Czech Republic $(8,9 \%$ and $12,2 \%)$, Hungary $(10,4 \%$ and $12,5 \%)$. This is due in particular to the increase in migration flows to these countries from South Africa because of the political, social and economic problems [18], which only exacerbates tensions and inequalities within EU. The average income of immigrants, immigrating within EU, in particular, male increased by $20,4 \%$, female - by $20,47 \%$, then immigrants who immigrate from other countries - by $14,47 \%$ and $14,36 \%$, respectively. Herewith, the wages of male immigrants from the EU significantly exceed the wages of female immigrants, and the difference is significant compared to the income of immigrants from countries other than EU, where male's income exceeds female's income by an average of 221 euros in 2010-2019.

Table 2. Median income of immigrants within EU-27 and non-EU-27 immigrants by sex (population aged 18 and over) in 2010-2019, euro

\begin{tabular}{|l|c|c|c|c|c|c|c|}
\hline \multicolumn{1}{|c|}{$\begin{array}{c}\text { Median equivalised net income, euro, } 18 \\
\text { years or over }\end{array}$} & 2010 & 2015 & 2016 & 2017 & 2018 & 2019 & Growth, \% \\
\hline \multicolumn{7}{|c|}{ EU-27 countries (from 2020) except reporting country } \\
\hline Males & 16725 & 17841 & 17759 & 18878 & 19302 & 20137 & 20,40 \\
\hline Females & 15772 & 17153 & 17231 & 17961 & 18328 & 19000 & 20,47 \\
\hline \multicolumn{7}{|c|}{ Non-EU-27 countries (from 2020) nor reporting country } \\
\hline Males & 13353 & 13861 & 14556 & 14321 & 15020 & 15285 & 14,47 \\
\hline Females & 13105 & 13746 & 13921 & 14153 & 14852 & 14987 & 14,36 \\
\hline
\end{tabular}

Pairwise correlation was used for analysis of the relationship between the indicators shown in Table 3. The analysis of the structure of the presented correlation matrix was carried out taking into account the significance of the correlation coefficients based on the Chaddock scale. 
The income of immigrants from EU countries is significantly related to participation in educational programs and trainings, as well as the income of immigrants from countries other than EU (see Table 3 ). At the same time, it is negatively related to the level of poverty of immigrants.

Table 3. Correlation between immigrants median income and education, training, poverty, needs for medical examination and GDP by within EU-27 immigrants and non-EU-27 immigrants

(based on panel data for EU countries in 2010-2019)

\begin{tabular}{|l|c|c|c|c|c|c|}
\hline & $\begin{array}{c}\text { Income_EU } \\
27\end{array}$ & $\begin{array}{c}\text { Income_Non- } \\
\text { EU27 } \\
\text { countries }\end{array}$ & $\begin{array}{c}\text { Participation rate in } \\
\text { education and } \\
\text { training }\end{array}$ & $\begin{array}{c}\text { Immigrants } \\
\text { At-risk-of- } \\
\text { poverty rate }\end{array}$ & $\begin{array}{c}\text { Self-reported } \\
\text { unmet needs for } \\
\text { medical } \\
\text { examination }\end{array}$ & $\begin{array}{c}\text { Gross } \\
\text { domestic } \\
\text { product }\end{array}$ \\
\hline Income_EU27 & 1,000 & & & & & \\
\hline $\begin{array}{l}\text { Income_Non-EU27 } \\
\text { countries }\end{array}$ & 0,990 & 1,000 & & & & \\
\hline $\begin{array}{l}\text { Participation rate in } \\
\text { education and training }\end{array}$ & 0,589 & 0,569 & 1,000 & & & \\
\hline $\begin{array}{l}\text { Immigrants At-risk-of- } \\
\text { poverty rate }\end{array}$ & $-0,624$ & $-0,645$ & $-0,451$ & 1,000 & & \\
\hline $\begin{array}{l}\text { Self-reported unmet } \\
\text { needs for medical } \\
\text { examination }\end{array}$ & $-0,476$ & $-0,506$ & $-0,066$ & 0,408 & 1,000 & \\
\hline Gross domestic product & 0,757 & 0,744 & 0,613 & $-0,440$ & 0,037 & 1,000 \\
\hline
\end{tabular}

In fact, low income determines the inability to ensure a decent quality of life, which also leads to the inability to obtain medical services and examinations. In particular, receiving medical services by immigrants from countries other than EU is more negatively linked to income, in particular due to income inequality. Herewith, the incomes of the two groups of migrants are significantly positively related to the GDP of EU countries. This means that immigration provides a significant contribution to the economic development of advanced countries, but does not address inequality and poverty issues.

These results indicate the heterogeneity of the effects of migration. In fact, migration provides a contribution to the economies of EU countries and a short-term contribution to the economies of immigrant countries. At the same time, legal migrants also contribute in the form of financing the income of migrants who have been unemployed for more than 12 months, namely in the form of social protection, thus, balancing the heterogeneity of consequences. The present research also confirms the theory of a new economics of labour migration, which provides an approach to understanding the contribution of migrants as income in order to ensure the current cost of living (ensuring the existence). At the same time, it is possible to simplify the theory statement of the new economics of labour migration in understanding migration as a reaction to income risk (when remittances insure households against poverty). Our investigation proves that immigrants' incomes cannot provide health care only by covering current living expenses. In addition, immigrants do not ensure income risks, but seek to maximize income due to the difference in wages in different countries. As a result, migrants' flows within EU are increasing, and flows of migrants from developing countries (Eastern Europe) are the largest. The present research complements the theory of the new economics of labour migration, considering this concept as a way to maximize income and reduce income risk through training, higher wages and a way to get better health and education services, access to developed infrastructure. However, the heterogeneity of the effects of migration is also reflected in the inability to obtain health services and access to the education system due to the high cost. All this exacerbates the problems of inequality and poverty due to the imbalance in both income and the cost of social services in various EU countries.

\section{Discussion}

The results of the research demonstrate the existence of systemic problems of migration policy in the context of sustainable development. Inequality, in particular gender one, unemployment and poverty remain key problems for immigrants within EU. As the present research shows, migration integration policies fail to achieve the goal of inclusive and equitable social-economic well-being. Inequality remains a major problem for sustainable development, in particular a gender one [6]. However, nowadays the goals of sustainable development only state the need to protect the rights 
of female migrants through the polarized approach of international institutions. The investigation of Thompson \& Walton-Roberts [19] notes females' migration after completing training in medical sphere due to greater opportunities abroad. Training should be considered in the context of sustainable development as ensuring access to the education system [20]. Our study provides evidence of an increase in participation in educational programs and trainings. "31 million school-aged children are international migrants, and this number is set to grow. Their education is, therefore, a long-term strategic priority and investment" [8]. This is in line with SDG (Sustainable Development Goals) 10.7 "well-ordered and responsible migration". Recognition of the value of female migrants' work is a solution to the problem of protecting the rights of the labour force in the field of care and the health care system, the demand for which is growing significantly due to non-recognition of the value outlined [7]. The gender-blind approach to migration does not take into account the subjectivity of women and their contribution to economic development, giving preference to economic growth at the national level [21]. Our research confirms these results by demonstrating the contribution of immigrants to GDP and, at the same time, lower wages for women.

The results of the study confirm the approach, proposed by De Haas, to migration and the theory of a new economics of labour migration. At the same time, alternative results have been found in understanding migration as a response to income risk, as this study proves that immigrants' incomes cannot provide medical, social services, insurance, but only cover current living expenses. The obtained results complement the theory of the new economy of labour migration, considering it in the context of sustainable development.

Migration policy should be flexible in order to address systemic problems in the context of sustainable development and labour market flexibility, protection of rights. As it has been pointed out by Tacoli \& Okali, controlling and restricting the flow of illegal migrants will not overcome inequality and poverty, but may widen the gap [13]. Raising wages in this context is extremely important in order to overcome inequality. Participation in migrants skills development programs through educational programs and trainings should be integrated into public policy as an incentive and a tool to ensure decent compensation. The main purpose of such a policy is to encourage migrants to develop qualified professional skills and employment. One of the methods to solve the problem is the inclusion of migrants, lifelong learning, and the integration of migration programs into EU policies.

\section{Conclusions}

The conducted research has made it possible to draw a number of important conclusions. Our investigation proves that migration policy should be the strategy's component of structural transformation of national economies; it should be considered as a signal for the development of the education system, health care, technology and infrastructure. Assessing the effectiveness of EU migration policy proves the absence of systemic changes in addressing inequality, security, poverty, economic growth in the context of sustainable development. Consequently, the problem of economic growth in the most developed countries has intensified with a simultaneous increase in inequality, in particular a gender one (Germany, Italy, Czech Republic, Hungary) due to an increase in migration flows and an increase in refugees.

Training and education programs should be integrated into migration policy as a tool to address income inequality, provide access to education and medicine through wage growth. Creation of legal channels for migration will ensure enhancing the protection of rights of low and highly qualified migrants, as well as more effective integration of immigrants into life within EU.

The present research complements the theory of the new economics of labor migration, considering this concept as a way to maximize income and reduce income risk. This is due to educational programs and training, a higher level of remuneration, the provision of wide access to quality medical and educational services, a developed infrastructure. However, the heterogeneity of migration's consequences is also reflected in the inability to obtain health services and access to the education system due to the high cost. All the outlined exacerbates the problems of inequality and poverty due to the imbalance in both income and the cost of social services in various EU countries.

The practical significance of the research lies in the possibility of using the results obtained by the governments of EU countries to develop lifelong learning programs for immigrants in order to reduce cost on social protection and strengthen the rights of migrants to decent wages.

\section{References:}


[1] Aniche, E. T. Migration and Sustainable Development: Challenges and Opportunities. In Migration Conundrums, Regional Integration and Development, 2020, pp. 37-61. Palgrave Macmillan, Singapore. https://doi.org/10.1007/978-981-15-2478-3_3

[2] Nyberg-Sørensen, N., Hear, N. V., \& EngbergPedersen, P. The migration-development nexus: evidence and policy options. International Migration, 40(5), 2002, pp. 4973. https://doi.org/10.1111/1468-2435.00211

[3] Yan, T., \& Qian, W. Y. Environmental migration and sustainable development in the upper reaches of the Yangtze River. Population and Environment, 25(6), 2004, pp. 613-636. https://doi.org/10.1023/B:POEN.0000039067.4 3303.66

[4] Gelb, S., \& Krishnan, A. Technology, migration and the 2030 Agenda for Sustainable Development. London: Overseas Development Institute. 2018. Available at https://sohs.alnap.org/system/files/content/reso urce/files/main/12395.pdf

[5] Hagen-Zanker, J., Mosler Vidal, E., \& Sturge, G. Social protection, migration and the 2030 Agenda for Sustainable Development. 2017. Available https://doc.rero.ch/record/308981/files/2410._ODI_Socialprotection.pdf

[6] Holliday, J., Hennebry, J., \& Gammage, S. Achieving the sustainable development goals: surfacing the role for a gender analytic of migration. Journal of Ethnic and Migration Studies, 45 (14: 1), 2019, pp. 2551-2565. https://doi.org/10.1080/1369183X.2018.145672 0

[7] Gammage, S., \& Stevanovic, N. Gender, migration and care deficits: what role for the sustainable development goals? Journal of Ethnic and Migration Studies, 45(14), 2019, pp. 2600-2620. https://doi.org/10.1080/1369183X.2018.145675 1

[8] Nicolai, S., Wales, J., \& Aiazzi, E. Education, migration and the 2030 Agenda for Sustainable Development, 2016. Available at https://doc.rero.ch/record/308985/files/286._ODI_Education.pdf

[9] Glover, S., Gott, C., Loizillon, A., Portes, J., Price, R., Spencer, S., ... \& Willis, C. Migration: an economic and social analysis, 2001. Available at https://mpra.ub.unimuenchen.de/75900/

[10] De Haas, H. The migration and development pendulum: A critical view on research and policy. International migration, 50(3), 2012, pp. 8-25. https://doi.org/10.1111/j.14682435.2012.00755.x

[11] Newland, K., \& Patrick, E. Beyond remittances: the role of diaspora in poverty reduction in their countries of origin, a scoping study by the Migration Policy Institute for the Department of International Development. Migration Policy Institute, 2004. Available at https://www.migrationpolicy.org/pubs/Beyond _Remittances_0704.pdf

[12] De Haas, H. Migration and development: A theoretical perspective. International migration review, 44(1), 2010, pp. 227-264. https://doi.org/10.1111\%2Fj.17477379.2009.00804.x

[13] Tacoli, C., \& Okali, D. The links between migration, globalisation and sustainable development. International Institute for Environment and Development and the Regional and International Networking Group. 2001.

[14] Heilmann, C. Remittances and the migrationdevelopment nexus-Challenges for the sustainable governance of migration. Ecological Economics, 59(2), 2006, pp. 231236.

https://doi.org/10.1016/j.ecolecon.2005.11.037

[15] Rawee Suwandechochai, Wasin Padungwech, Heuristic Algorithms for Surveyor Standby Location Planning with Multiple Plans, International Journal of Circuits, Systems and Signal Processing, Vol.14, 2020, pp. 11541161.

[16] Qin Wang, A Fuzzy Comprehensive Evaluation Method of Area Resource Carrying Capacity, International Journal of Circuits, Systems and Signal Processing, Vol. 14, 2020, pp. 11371153.

[17] Eurostat, Database, 2020. Available at https://ec.europa.eu/eurostat/web/main/data/dat abase?p_p_id=NavTreeportletprod_WAR_Nav Treeportletprod_INSTANCE_nPqeVbPXRmW Q\&p_p_lifecycle $=0 \& p \_p \_s t a t e=$ normal\&p_p mode $=$ view

[18] Cobbinah, P. B., Erdiaw-Kwasie, M. O., \& Amoateng, P. Africa's urbanisation: Implications for sustainable development. Cities, 47, 2015, pp. 62-72. https://doi.org/10.1016/j.cities.2015.03.013

[19] Thompson, M. \& Walton-Roberts M. International Nurse Migration from India and the Philippines: The Challenge of Meeting the Sustainable Development Goals in Training, Orderly Migration and Healthcare Worker 
Retention. Journal of Ethnic and Migration Studies, 45 (14), 2019, pp. 2583-2599. https://doi.org/10.1080/1369183X.2018.145674 8.

[20] Elias, J., \& Holliday, J. Who Gets 'Left Behind'? Promises and Pitfalls in Making the Global Development Agenda Work for Sex Workers - Reflections from Southeast Asia. Journal of Ethnic and Migration Studies, 45 (14), 2019, pp. 2566-2582. https://doi.org/10.1080/1369183X.2018.145674 7.
[21] Hennebry, J., Hari, K. C., \& Piper, N. (). Not without them: Realising the sustainable development goals for women migrant workers. Journal of Ethnic and Migration Studies, 45(14), 2019, pp. 2621-2637. https://doi.org/10.1080/1369183X.2018.145677 5

\section{Creative Commons Attribution License 4.0 (Attribution 4.0 International , CC BY 4.0)}

This article is published under the terms of the Creative Commons Attribution License 4.0 https://creativecommons.org/licenses/by/4.0/deed.en US 